\title{
Border Management and Threats to Internal Security
}

\author{
Dr Pushpita Das*
}

\begin{abstract}
India's borders has been grappling with a number of threats from across the border such as cross-border movement of terrorists, insurgents, illegal migrants as well as trafficking of drugs weapons and fake Indian currencies. These cross-border threats, which invariably either originate in the neighbouring countries or are nurtured by them pose a major challenge to the internal security of the country. In response to these cross border threats, the Government of India has crafted a comprehensive border management system to secure its borders. The component of the system include - border guarding, border regulation, development of border areas and bilateral institutional mechanism. However, factors such as lack of or inadequate manpower and financial resources, rigid rules and regulations, corruption, non-cooperative states governments, etc. hamper the functioning of this system. The government should address these inadequacies by sanctioning adequate resources for strengthening manpower and infrastructure along the borders as well as constructively engage with both border residents and neighbouring countries.
\end{abstract}

Keywords: India, Border management, Security Threats, Cross-Border threats, trafficking, non-traditional threats, terrorism, gun-running, Internal Security

* Dr. Pushpita Das is Research Fellow \& Centre Coordinator (Internal Security), Institute for Defence Studies and Analyses, New Delhi. 


\section{Border Management and Threats to Internal Security}

\section{Introduction}

Borders are often described as the outer membranes of a state that protects the territory it encloses by permitting the circulation of people, goods, and ideas, while at the same time blocking entry of harmful elements. In other words, borders perform interrelated but contradictory functions to protect the state they enclose. On one hand, borders act as barriers to undesirable elements such as goods, services, capital, people, and ideas considered harmful for the domestic territory and population. On the other, they serve as bridges to facilitate legitimate socio-economic and cultural exchanges across countries.

Border management is the process by which countries exercise control at their borders and optimize the functioning of their borders. This includes border security-preventing unauthorized crossings, and trade and travel facilitation-allowing rapid movement of authorized people and goods with minimal interference (Gerstein, Atler, Davenport, Grill, Kadlec \& Young, 2018, pp. 3-4). Effective border management requires a precise conception of what constitutes a legitimate crossing and what an irregular crossing and therefore a threat. Equally, it requires policy solutions and judicious deployment of resources to tackle the threat as well as allow efficient clearance of legitimate cross-border traffic. Border management, thus, involves development of appropriate policies and legislation, administrative structures, operational systems and human resource base to respond effectively to diverse challenges.

Proper management of borders is critical as it has a direct implication on internal security of a country. Internal security is defined as "security against threats faced by a country within its national borders, either caused by inner political turmoil, or provoked, prompted or proxied by an enemy country, perpetrated even by such groups that use a failed, failing or weak state, causing insurgency, terrorism or any other subversive acts that target innocent citizens, cause animosity between and amongst groups of citizens and communities intended to cause or causing violence, destroy or attempt to destroy public and private establishment" (Puncchi, 2010, p. 5). This definition brings out the fact that the internal security of a country is vulnerable to inimical forces which lay beyond and therein lies the significance of safeguarding the country's borders. States, be it ancient, medieval or modern, have implemented security 
measures such as raising border guards, building walls, patrolling, passport controls, etc. to secure their borders against intruders.

India has been grappling with various threats emanating from across the borders such as infiltration by terrorists and insurgents, smuggling of arms and ammunition, trafficking of narcotics \& drugs, fake Indian currency notes (FICN) as well as persons, illegal migration, trans border crimes, etc. Most of these threats have strong cross-border links as they either originate in the neighbouring countries or are nurtured by them with the sole objective to destabilise India. In response to these cross border threats, the Government of India has crafted a comprehensive border management system to secure its borders. The component of the system include - border guarding, border regulation, development of border areas and bilateral institutional mechanism.

This article begins by discussing the types of threats that India faces along its borders, followed by an analysis the security measures taken by the Indian government to address the threats. It then discusses the factors that constrain the effective management of the country's international borders. The article concludes by forwarding a few recommendations.

\section{Cross-border Threats}

\section{Exfiltration and Infiltration by Insurgents and Terrorists}

Since the inception of insurgency in the Northeast in the 1950s, the Naga insurgents have been crossing over into Myanmar, especially in the Kachin state and the Sagaing Region. The trend of such cross-border movements of insurgent groups became more pronounced since the late 1960s after the Meiteis, the Mizos, the Tripuris, and the Assamese rebelled against the Indian state. These insurgents cross the borders mainly to set up bases where they can rest, recoup, train, plan, and launch future offensives as well as hide when pursed by the Indian security forces. While a porous and poorly guarded border coupled with a strong cross-border ethnic linkages enabled the insurgents to cross the borders with ease, the tacit approval of the Myanmar government (Egreteau, 2008, p. 947) and the active support of the Bangladesh government (Bhasin, 2003, p. 2068) facilitated the establishment of these safe havens in these countries. Around 150-200 insurgent camps existed in the Chittagong, Khagrachari, and Sylhet districts before there was a change in the mind-set of ruling elite in Bangladesh against 
terrorism and they dismantled those insurgent camps ("Almost zero insurgent camps", 2017). The Bhutanese territory was similarly exploited by the insurgent groups from Assam to establish bases in the 1990s (Ministry of Home Affairs, 2005, p. 39).

Attempts by terrorists and militants to infiltrate into Indian Territory from Pakistan through the international boundary has been a recurring challenge. Infiltration was extremely high during the 1980s and 1990s when Punjab and Kashmir militancy were at their peak. To cite an example, between 1986 and 1992, security forces in Punjab had apprehended 45,650 persons trying to cross the international border (Swami, 2004, p. 157) and had seized around $2500 \mathrm{AK}$ series of assault rifles in the state (Smith, 1995, p. 69). By the mid-1990s, Pakistan had also started sending its own jihadi terrorists and veterans of the Afghan war to revive the flagging insurgency in the state. It is important to mention that the level of terrorist violence in $J \& K$ is closely linked to infiltration across the border and action against terrorists.

Terrorist groups active in neighbouring countries also sneak into India for shelter as well as to perpetrate acts of terror. According to a media report, the Bangladesh government had informed the Indian government that an estimated 2010 extremists belonging to the Harkat-ul-Jihadi alIslami (HuJI) and Jamaat-ul-Mujahideen Bangladesh (JMB) had entered India between 2015 and 2017 (Gupta, 2017) Investigations have revealed the role of these foreign terror operatives in various terror related incidents in the country ("Four JMB terrorists get 7 years", Indian Express, 2020).

\section{Gun-running}

While militancy/terrorism requires funds, support, recruits, and infrastructure to thrive, weapons and munitions constitute a major requirement for its sustenance. The ability of any militant/terrorist group to procure and maintain a flow of weapons is essential for their military strength to threaten the State and challenge public order. The military strength of a group also influences its ability to gain attention, public support and new recruits.

In this aspect, the Northeast insurgent groups have been able to acquire weapons quite easily from various sources such as covert arms markets of Southeast Asia, the Yunnan mafia having access to Chinese state-run ordnance factories (Upadhyay, 2009, p. 55), and the United Wa State Army (UWSA). The bulk of the weapons purchased from the black markets in Thailand 
and Cambodia are shipped through the Andaman Sea to the Cox's Bazaar in Bangladesh, and thereafter to different parts of the Northeast through the thickly forested tracks of Meghalaya, Tripura, and Mizoram borders (Karlekar, 2014). Weapons produced in China are routed across the Myanmar border at Ruili, and enter the Indian border through Phek, Chandel, Churachandpur, and Champai (Bhattacharyya, 2010, p. 56). The India-Nepal border has in recent years become an easy route for the smuggling of Chinese sourced weapons for the Northeast insurgent groups.

\section{Trafficking of Narcotics and Drugs}

Proximity to the narcotics and drugs producing regions of the Golden Triangle (MyanmarThailand-Laos) and Golden Crescent (Afghanistan-Pakistan-Iran), coupled with a porous and poorly guarded international border, have made India a transit hub as well as a destination for heroin, hashish, and psychotropic drugs produced in these regions. In addition, various psychotropic pharmaceutical preparations and precursor chemicals produced domestically are also trafficked through the Indian Territory. Heroin was first trafficked into India in the midseventies from the Golden Triangle, which picked up by eighties.

The Golden Crescent, however, has remained the primary source of trafficked heroin and hashish in the country since the early eighties when traffickers started rerouting heroin from this region through India following the Iran-Iraq war. Although the end of the war and reopening of the Balkan trafficking route in late eighties resulted in a dip in heroin trafficking in the country, but the trend did not sustain. After a gap of almost two decades, it again picked up in 2012 (Narcotics Control Bureau, 2015, p. 8). Increased production of opium in Afghanistan, greater domestic demand in India, and connivance of state government officials and border guarding forces together contributed towards this increase in heroin trafficking, especially in the Punjab sector.

Apart from narcotics, India has been experiencing a significant rise in the use of psychotropic substances and medicinal preparations since the late 1990. Amphetamine Type Stimulant (ATS) and methamphetamine produced in large quantities in Southeast Asia especially in the Golden Triangle, are trafficked into India through the porous India-Myanmar border. In a reverse flow, pharmaceutical preparations containing dextropropoxyphene and codeine are 
trafficked from India to the neighbouring countries. Lately, trafficking of cocaine into India has been observed, a result of diversification of cocaine markets is globally.

This two way illegal movement of narcotics and drugs pose a significant threat to the national security. For one, the breach of the international borders of the country by drug traffickers implies that that the same routes could be used for smuggling in weapons as well as terrorists into the country. In fact, it has been established that the arms and explosives used in the 1993 serial bomb blasts in Mumbai were transported by the Dawood Ibrahim gang through the traditional trafficking routes (Kalyanaraman, 2010, pp. 706-707). Investigations into the Pathankot attack that took place on 31st December 2015 also hinted that the terrorists entered into India from Pakistan through the routes tried and tested by drug traffickers (Patil, 2018). Further, the money generated by the illegal sale of narcotics and drugs is used for financing terrorist activities. In India, the Kashmiri, Sikh and Northeast militants have used drug money to finance their 'struggle' against the Indian state (Jamwal, 2002, p. 143; Shivananda, 2011).

\section{Trafficking of Fake Indian Currency Notes (FICN)}

India has been experiencing smuggling of high quality counterfeit Indian currency notes since the1990s. The fact that the counterfeiting of high denomination Indian currency requires sophisticated machines and capital investment indicates that it is not a petty criminal activity, but a well-orchestrated state sponsored enterprise, intended to adversely impact India's economic security (Shapoo, 2016). Many experts have termed smuggling of FICN as 'economic terrorism' because it is orchestrated to generate inflation and deprive government of its legitimate revenues as well as used for terror financing. While India had always known that the Inter Services Intelligence (ISI) was behind this act of economic terrorism against India, it was only in 2013 that the National Investigation Agency (NIA) conclusively established Pakistan's role in printing high quality FICN and pushing them into India. Forensic analysis by the NIA has revealed that the paper used for printing counterfeit rupee notes matched perfectly with the legal tender of Pakistan (Sharma, 2013; Tripathi, 2017).

Initially, the India-Pakistan border was exploited to push in FICN, but later on it started channelling in FICN through almost all the land borders of India. The India-Bangladesh border has become particularly vulnerable to the trafficking of FICN, with Kalaichak in the Malda district together with several adjoining areas in Malda and Murshidabad districts becoming 
nerve centres for FICN trafficking (De, 2018). Between 2010 and 2015, FICN valued between 24 crores and 44 crores have been seized in India (Ahir, 2016). However, since the withdrawal of legal tender status of bank notes of denomination of Rs. 1000 and Rs. 500 in November 2016, there has been no reported cases of seizure of high quality FICN (Sitharaman, 2019).

\section{Illegal Migration}

One of the major consequences of a porous border is the easy and illegal crossing of the border. Bangladesh has been a major sources of illegal migration into India. Political upheavals, religious persecution, demographic pressures, and environmental crises are some of the 'push' factors that have contributed to the large-scale influx of Bangladeshis into India. The 'pull' factors that attract migrants from Bangladesh to India are the availability of land, access to facilities like employment opportunities, medical care, education, and similar cultural landscapes.

While it is an established fact that illegal migration from Bangladesh has been taking place unabated over the decades, there have been no authentic official statistics to ascertain the actual number of illegal migrants in India. However, the Government of India has periodically provided statistics on the estimated number of illegal migrants in India. The latest figures state that an estimated 20 million Bangladeshis are staying illegally in India ("Two crore illegal Bangladeshis living in India”, 2016).

Illegal migration has, and will continue to have, a severe negative impact on the internal security of the country. The impact of illegal migration on the country's security can be assessed in two ways. First, the political instability caused by the mobilization of popular perception against them by political elites to grab political power, and the resultant conflict over scarce resources, economic opportunities, and cultural dominance. In Assam and Tripura, the resistance to Bengali migrants has socio-economic, cultural and political dimensions, which have brought the issues of ethnicity and migration to the fore.

On the one hand, the assertion of ethnicity by locals soon morphed into raging insurgencies, which plunged the entire border region into a spiral of violence and instability. On the other hand, persistent attacks against illegal migrants especially Muslims, in Assam has unfortunately given way to radicalization within certain sections of the Muslim community. These radicalized persons formed militant organizations such as the Muslim United Liberation 
Tigers of Assam (MULTA), the Muslim United Liberation Front of Assam (MULFA), etc., which profess jihad against India to avenge the attacks ("Muslim United Liberation Tigers of Assam”, n.d.).

The second aspect impacting internal security is the undermining of the rule of law and integrity of the country by illegal migrants engaged in illegal and anti-national activities. The presence of a large number of illegal migrants in the border areas has created a 5-10 km deep zone peopled by poor Bangladeshis. This has not only blurred the international border, but also made the border areas a breeding ground for criminals and anti-national elements.

Mafias operating in these grey zones solicit the illegal migrants to act as their couriers, who happily collude with them in return for easy money or a hassle-free stay in India. They smuggle cattle, consumer items, drugs and narcotics, arms as well as human beings across the border through the well-established smuggling networks (Nandy, 2005, pp. 140-141).

Given these threats and challenges, Government of India has crafted a comprehensive approach towards border management which involves guarding the borders against infiltrators, efficient facilitation of trade and travel at designated entry points, development of the border area, and seeking cooperation of the neighbours.

\section{India's border management system}

India's border management system has four main elements: 1) border guarding, 2) border regulation, 3) development of border areas, and 4) bilateral institutional mechanisms. Following paragraphs analyses these fours elements of India's border management system

\section{Border guarding}

Physically guarding the international borders between various designated ports of entry and exit along the border forms the first element of India's comprehensive border management system. World over, the task for guarding the borders is undertaken by border guarding forces involving either the military or the armed police force. In the case of India, the guarding of its international borders is primarily entrusted to four central armed police forces (CAPFs) under the principle of 'one border one force' (Reforming National Security System, 2001, p. 61). 
These are the Assam Rifles (AR) guarding the India-Myanmar border, the Border Security Force (BSF) guarding the India-Pakistan and India-Bangladesh borders, the Sashastra Seema Bal (SSB) policing the India-Nepal and India-Bhutan borders, and the Indo-Tibetan Border Police Force (ITBP) guarding the India-China border. Besides, the Indian army guards the line of control (LOC) on Pakistan border with BSF and line of actual control (LAC) along IndiaChina border with ITBP (Ministry of Home Affairs, 2019, p. 35).

These border guarding forces are, in general, deployed in a linear pattern along the international borders to cover the maximum area. 'Area dominance' is the method employed by the border guarding forces to guard India's borders. Under the method, a string BOPs is established all along the borders. The BOPs "are meant to provide appropriate show of force to deter transborder criminals, infiltrators and the hostile elements from indulging in the activities of intrusion/ encroachment and border violations" (Ministry of Home Affairs, 2019, p. 35).

The primary task of the BOPs is to send out regular patrols to areas under its responsibility for effective border surveillance and domination. Parties sent out on patrols also interact with the local people to gather tactical intelligence. Units of the Border Police, the border wing of the Home Guards as well as members of the Village Volunteer Force (VVF) of different border states also participate in the patrolling of the international borders (Singh, 1999, pp. 125-126).

India has also been erecting physical barriers in the form of fences to prevent the illegal ingress and egress of people and goods. The construction of fences began in the mid-1980s with the erection of fences the India-Bangladesh to prevent the illegal migration and the India-Pakistan borders to stop the movement of Sikh militants as well as smuggling of narcotics (Ministry of Home Affairs, 1989, pp. 7-8). Fences have also been constructed along the J \& K border as the state faced the dual threat of infiltration by terrorists and trafficking of narcotics (Ministry of Home Affairs, 2008, p. 30). Furthermore, a 4 km long fence along the international border at Moreh (between pillars no. 79 and 81) in Manipur has been built as this stretch is most porous to the movement of insurgents and traffickers (Ministry of Home Affairs, 2013, p 35). At present, a total of 5060 kilometres of fences have been erected along India's borders and a substantial portion of these fences (approximately 4401 kilometres) have been floodlit to enhance the operational effectiveness of the forces guarding these borders during night. Besides, $3660.70 \mathrm{~km}$ border road has been constructed along India-Bangladesh border to provide rapid mobility to the BSF personnel (Ministry of Home Affairs, 2019, pp. 36-39). 
These efforts are supplemented by remote surveillance of the border through various electronic equipment such as hand held thermal imageries, night vision goggles, battle field surveillance radars, etc. In addition, the Indian government is also exploring new systems involving greater use of high technologies to effectively secure the international borders. The Comprehensive Integrated Border Management System (CIBMS), which comprises an array of sophisticated sensors, cameras and detectors, is presented as a robust and integrated system which aims to improve the "situational awareness" of the border areas by replacing manual surveillance with high tech equipment as well as reaction capabilities of the border guarding forces. At present, the CIBMS is installed in three stretches along the India-Pakistan and India-Bangladesh borders - two in Jammu sector and one in Dhubri sector (Ministry of Home Affairs, 2019, p. 40). If the system is successfully implemented then it will be a paradigmatic shift in the way India's international borders are guarded.

\section{Regulation at the Borders}

Facilitating legitimate trade and travel through designated points of entry and exit along the international borders while giving due regard to the security of the country is the second element of border management. Regulation involves two conflicting processes: first, maintaining control and regulating the cross-border movement of people and cargo through a range of interventions, such as documentary and physical monitoring, screening, scanning and testing; and second, enabling efficient trade and travel by minimising the impact of interventionist strategies as far as possible (Widdowson \& Holloway, 2011, p. 98).

In India, the points of entry and exit at the border are land customs stations, some of which are upgraded as integrated check posts (ICPs). Typically, an ICP houses all the regulatory agencies, such as customs, immigration, and border guarding forces as well as support services such as plant and animal quarantine, foreign exchange bureau, banking, parking, etc. in a single complex. It is also equipped with a state of-the-art scanning and detection devices, such as metal detectors, X-ray machines, scanners, besides having a passenger facilitation area and a cargo area for processing imports and exports within the complex (Ministry of Home Affairs, 2019, p. 48).

In addition, to facilitate legitimate travel while strengthening security through a centralised database, India has implemented a scheme, the Immigration, Visa and Foreigners Registration 
\& Tracking (IVFRT) (Ministry of Home Affairs, 2019, p. 234). Passport Reading Machines (PRMs) and Questionable Document Examiner (QDX) machines are also installed in immigration points to detect forged documents.

As far as ensuring efficient cross-border trade is concerned, India ratified the Trade Facilitation Agreement (TFA) in April 2016, and constituted a National Committee on Trade Facilitation (NCTF) under the Chairmanship of the Cabinet Secretary (Ministry of Commerce \& Industry, 2017). On 20 July 2017, the NCTF adopted a 76-point National Trade Facilitation Action Plan 2017-2020 which aims at transforming the "cross border clearance eco-system through efficient, transparent, risk based, coordinated, digital, seamless, and technology driven procedures which are supported by state of-the-art sea ports, airports, land border crossings, rail, road and other logistics infrastructure" (Central Board of Indirect Taxes and Customs, n. d.). The Plan states that trade facilitation comprises four components: Transparency (access to information); Technology (digital and detection); Procedures (simplification, standardisation, harmonisation and risk based approach); and Infrastructure (augmentation in road and rail connectivity, improvement of sea and air ports, and land customs stations). These measures are being implemented through intra-government and inter-agency cooperation and collaboration (Central Board of Indirect Taxes and Customs, n.d.).

\section{Development of Border Areas}

The third main element in India's border management system is the development of border areas. Being at the periphery and proximate to the neighbouring country, border areas face difficulties which are normally not experienced in the hinterland. Issues of security and accessibility are two of the most prominent problems experienced by people living along the borders, albeit the magnitude of these problems differ from one border area to another.

In view of the distressing situation along the international borders, the Union government realised that these areas required special government intervention for their overall development so that the people are relieved from their daily predicaments, and feel a sense of belonging. Accordingly, it launched the Border Area Development Programme (BADP) in 1986 (Planning Commission, 1992). Broadly, the aim of the BADP is to meet the infrastructural needs of the people residing in the border areas, develop skills and generate employment to wean border residents away from illegal activities, and installing a sense of security among them. At present, 
the programme covers 396 border blocks in 111 border districts of 17 States located along the international land border (Ministry of Home Affairs, 2019, p. 42). Schemes taken up under the BADP in various sectors such as education, health, agriculture, and allied activities, employment generation, connectivity, etc., in general, have created a conducive atmosphere for undertaking economic activities as well as potentially improving the quality of life of people residing in these far-flung and remote areas (Planning Commission, 2013, p. 327).

Along with BADP, border trade as per the prevailing customary practices including border haats is also encouraged as an alternative means of earning for the border people in the economically depressed areas. The idea is to allow the border people to trade their surplus produce in exchange of essential commodities. Successful conduct of border trade also curbs smuggling in essential items as it provides legitimacy to traditional exchange of commodities, besides promoting psychological well-being of the border inhabitants. Border trade is a trade in local products of limited value barter in nature. While India had border trade with its neighbour after independence, but wars with China and Pakistan had disrupted these economic interactions. However, as bilateral relations improved, border trade between India and its neighbours commenced once again.

India re-started border trade first with China in 1992 through Lipulekh. Subsequently, Shipki La and Nathu La were added in 1993 and 2003 respectively (Ministry of External Affairs, 2004, p. 16). India and Myanmar re-started border trade along Moreh in 1994 and Zowakhthar in 2004 (Agreement between India and Myanmar on Border Trade, 1994). In 2008, India started cross LoC trade through the Uri and Poonch posts. The trade has suspended since 2019 because of the misuse of the trading routes for smuggling of drugs and weapons (Ministry of Home Affairs, 2019, p. 19). Lastly in 2011, India opened a border haat along the India-Bangladesh border in Kalaichar, which increased to four in 2017 (Chakraborty, 2020).

The resumption of border trade with the neighbouring countries has resulted in significant tangible as well as intangible gains, both to the bilateral relations as well as to people residing along various borders. The successful conduct of the trade, and the positive changes that it has brought about in the lives of the people, have induced a number of border communities as well as State governments to demand/request the reopening of additional trade routes. Even though border trade constitutes a miniscule part of India's over all international trade with its neighbours, and affects a small population residing in the peripheral areas, yet it has played a 
significant role in India's neighbourhood policy. India has successfully employed the instrument of border trade to constructively engage with its neighbours.

\section{Bilateral Institutional Mechanisms}

The fact that borders cannot be secured without the active cooperation of neighbours is well known. Security threats and challenges faced by countries along their mutual borders are similar and, therefore, cooperation and coordination between countries are essential for their effective management. Such cooperation and coordination enable neighbours to establish institutional interactions to raise, discuss, and resolve disputes. These institutional conflict resolution mechanisms also help in jointly addressing security challenges by pooling resources, and developing common border management strategies. These interactions contribute in allaying distrust, building confidence, and developing a spirit of coordination and cooperation between neighbours and their national agencies. India and its neighbours have also established several bilateral institutional mechanisms to address border disputes as well as manage threats and challenges that make their border vulnerable.

One such institutional mechanism is the bilateral interactions between officials of concerned agencies of India and its neighbours. These institutionalised interactions takes place regularly at national, regional and local levels to facilitate bilateral dialogue on matters of mutual concern regarding border management (Ministry of Home Affairs, 2019, pp. 203-206). For instance, border liaison meetings between the border guarding forces of India and its neighbours are held to maintain peace and tranquillity along the border and resolve local tensions caused by inadvertent violations of each other's territory by security forces as well as by the trans-border movement of insurgents and terrorists, narco-traffickers, illegal migrants and criminals. Another set of meetings takes place between the surveyors general of India and its neighbours to discuss the work plan for joint inspection, repairs, restoration and maintenance of boundary pillars as well as joint survey construction/relocation of missing pillars along the border (Survey of India, 2018, pp. 5-8).

In addition, several joint working groups (JWGs) have been constituted to provide frameworks for resolving contentious boundary issues festering between India and its neighbours. In this regard, India and Bangladesh constituted two Joint Boundary Working Groups - I \& II (JBWGI \& II) in 2001 to deal with the completion of the $6.1 \mathrm{~km}$ of the un-demarcated stretch, and 
modalities relating to the exchange of enclaves and adverse possessions between as well as the erection of boundary pillars (Bhasin, 2003, pp. 2168-2169). Efforts of the two JBWGs bore fruits in 2015 when India and Bangladesh successfully resolved the boundary disputes between them (“India, Bangladesh swap border enclaves, settle old dispute", 2015).

Similarly, India and Nepal set up the Joint Technical Level Nepal-India Boundary Committee (JTLNIBC) in 1981 to demarcate the India-Nepal border (Bhasin, 2005, p. 2827) and after years of surveying, deliberations and extensions, the Committee, in 2007, delineated 98 per cent of the India-Nepal boundary, excluding Kalapani and Susta. Subsequently, a boundary working group (BWG) was constituted in 2014 to construct, restore, and repair boundary pillars, including clearing the "no man's land" ("Nepal, India decide to set up boundary working group”, 2014). In the case of Bhutan as well, the India-Bhutan Group on Border Management and Security was constituted to discuss ways of improving the security environment in the border areas (Ministry Home Affairs, 2019, p. 41).

These bilateral institutional mechanisms have provided a conducive platforms for India and its neighbours to discuss issues border management and sensitise each other about their security concerns. The implementation of the coordinated border management plan and SOP for repatriation of victims of human trafficking between India and Bangladesh as well as the formalisation of Free Movement Regime (FMR) and the facilitation of movement of people through the land border with Myanmar are some of the positive outcomes of the processes of institutionalised engagements. In addition, initiation of border trade acted as a robust confidence building measure between India and its neighbours besides bringing prosperity and a sense of well-being for the inhabitants of the remote areas (Das, 2014, pp, 3).

\section{Factors undermining the border management system}

The adoption of a comprehensive system for border management has indubitably improved the security of India's international borders. However, persistence of threats in the form of terrorist infiltration, illegal migration, trafficking and smuggling of narcotics and weapons across the borders indicate that several inadequacies exist in the system which required urgent attention and remedy. Some of these shortcomings are discussed below: 
Shortage of manpower and infrastructure: Shortage of manpower in all the border guarding organisations has adversely affected their operational capabilities. While the Union government had sanctioned raising of additional battalions (Ministry of Home Affairs, 2009, p. 21), but the problem still remains acute. One of the major reasons is the high rate of attrition among border guarding personnel because of personnel reasons, health issues, or poor working conditions ("Voluntary retirement in paramilitary forces rises by $450 \%$, Rijiju tells Rajya Sabha", 2018). Secondly, a number of units of the border guarding forces are deployed for internal security duties such as anti-naxal operations, election duties and aiding states in maintaining law and order. As a result a large number of personnel are pulled out of the borders thereby compromising security at the borders. Third, a number of personnel go for training or on leave leaving the unit with reduced strength.

The lack of adequate infrastructure is also an issue of concern. A majority of the BOPs along the border are kachcha structures and do not have enough room to house the personnel or offer basic necessities such as drinking water (Department related Parliamentary Standing Committee on Home Affairs, 2018). Further, many units deployed along the borders do not have modern electronic equipment for remote surveillance and in places where they are deployed, most of these equipment do not function as they are either damaged or component to run it is not available. Moreover, personnel handling these sophisticated equipment are not adequately trained resulting in suboptimal utilisation of these equipment.

Delays in implementation of projects: A number of infrastructural projects such as fences, ICPs, roads, etc. that were sanctioned by the Union government for effectively secure the borders are witnessing slow pace of implementation. Several factors cause delays. Problems in acquisition of land because of bureaucratic hurdles, poorly maintained land records and uncooperative state governments is a major obstacle in the implementation of the projects. (Department Related Standing Committee on Home Affairs, 2017). For example, construction of border fences is pending in many place in West Bengal as the state government could not provide land on time (Mehta, 2019). Late submission of detailed project reports and late approval by concerned ministries is another factor in delaying the initiation of the projects. Furthermore, stringent environment regulations, inadequate funds and resources, lack of required local expertise, hostile border people, etc., all contribute towards slowing down the progress of the projects. 
Lack of Coordination among agencies: Poor coordination among the concerned organisations is one of the major challenges in efficiently managing the country's border, especially at the points of entry and exit. An estimated 12 different ministries and departments are involved in securing and managing India's borders - both at the central and state levels. The involvement of such an array of agencies invariably leads to coordination problems stemming from factors such as a lack of common understanding about the threats and challenges to borders, absence of proper channels of communication, turf wars and differing organisational goals of the concerned agencies. This lack of coordination is most glaring during the intelligence-sharing meetings, which take place once a month. The BSF, being the Lead Intelligence Agency (LIA) organises these meetings, but the level of participation from other agencies, especially the civil administration has been poor (BSF officials, personal communication, December 12, 2019). Most of the agencies also do not share information/intelligence with other agencies to earn brownie points. Further, an instance systemic mismatch is observed in the operation of customs department. Although one of the goals of the customs department is anti-smuggling, its goals of revenue maximisation through facilitation of trade, more often than not, compel its officials to relax security norms (Dogra, 2012).

Corruption: Connivance of the border guarding forces in letting smugglers, criminals, as well as ordinary people through the border is one of the major reasons for breaches of the international borders. For instance, the BSF personnel are notorious for demanding money from Bangladeshi migrants to look the other way when these illegal migrants cross the international border. Along the India-Bangladesh border each tout or smuggler is "assigned specific patches along the border, locally called the ghats, to facilitate border crossings by prospective immigrants and smugglers" (Nandy, 2005, p. 85). These touts bribe the corrupt BSF and state police personnel as well as local politicians for facilitating these unauthorised cross-border movements. The border-guarding personnel also collude with the drug peddlers for economic benefits. Investigations on drug trafficking cases in Punjab have revealed the BSF personnel take bribe to let drug traffickers sneak in heroin and weapons into the country (Sahay, 2020, Kanwal, 2016). In addition, one of the reasons for the shoddy implementation of development projects in the border areas is rampant corruption by local politicians and bureaucrats who siphon off funds meant for the projects. The absence of people's participation in these projects further reduces their transparency (Niti Aayog, 2015). 
Uncooperative neighbours: India's limited success in soliciting the cooperation of its neighbours in managing their mutual borders have also hampered effective border management. Some of its neighbours have been actively supporting and abetting terrorist groups and facilitating their infiltration into India as well as obstructing construction of border as fences and ICPs. For instance, Bangladesh has always protested against the building of fences by India and in past it had resorted to violence to stop its construction as well (Ghosh, 1989, p. 85). Similarly, Myanmar has objected to the construction of the ICP at Moreh claiming that the land on which the ICP was being built belonged to them ("Checkpost site at Moreh our land, says Myanmar", 2013). Both Bangladesh and Myanmar are also not warm towards the idea of opening up additional border haats to benefit the border people and have remained noncommittal towards developing required infrastructure along their borders. Thus, mutual distrust, hostility, and unfavourable political dispensation, have prevented the bilateral mechanisms to function efficiently and help India manage its borders effectively.

\section{Conclusion}

While implementation of a comprehensive mechanism for border management has improved security and efficiency of India's international borders, persistence of various cross-border threats, especially infiltration by terrorists and trafficking of narcotics etc., indicate that India has to continuously balance between softening its borders to enable legitimate trade and travel and hardening them as a barrier against cross-border terrorism and crime. In fact, the terror attacks on military stations in Pathankot and Uri are grim reminders that unless the borders are not properly secured, the country's security will continue to remain vulnerable.

The need of the hour is to address the inadequacies that are undermining the current border management system. To start with, the problem of manpower shortage among various border guarding forces should be addressed and their working and living conditions improved. Concomitantly, the training of the border guarding forces should be customised not only to acquire greater technological skills but also to sensitise them about the local culture and tradition. This is important because an understanding of the local cultural milieu will facilitate meaningful dialogue between the border guarding personnel and the local people and help them garner local support for their activities. At the same time, the government should undertake sustained community interaction programmes to sensitise the border residents about their strategic location and encourage them to work as 'ears and eyes' for the security agencies. The 
government should also encourage the local people to participate in their own economic development and develop a stake in keeping the borders peaceful and crime free.

The next issue that the government should focus on is to cut down on delays in land acquisition and environmental clearance for development of infrastructure and improve connectivity in the border areas. While remedial actions are being initiated to address these issues, the one thing that the Union government should do to expedite this process is to persuade the concerned state governments to understand the importance of border management and actively participate/cooperate in implementing various measures to improve the security and efficiency along the country's international borders. Furthermore, the Union government should ensuring greater coordination and synergies among concerned organisations involved in border management by establishing coordination committees at the district and state levels. These committees should include representatives from local civil administration, border guarding forces, customs, immigration, narcotics bureau, etc., and should meet regularly to discuss border security and management issues.

Last but not least, international borders are best managed when neighbours cooperate to secure their mutual borders. For such cooperation to materialise, political and diplomatic initiatives require to be carefully crafted. India has been constructively engaging its neighbours so that they remain sensitive to India's security concerns. In fact, military operations undertaken by Myanmar and Bhutan to crack down on Indian insurgent groups as well as handing out leaders of insurgent groups by Bangladesh are successful outcomes of these engagements. India should maintain this momentum of constructive engagements with its neighbours. It can further deepen such cooperation by assisting its smaller neighbours in strengthening their border guarding capabilities by providing them with training and resources. Development of the shared border areas is yet another area of cooperation that India should explore with its neighbours for a secure and peaceful border.

\section{References}

Agreement between Government of the Republic of India and Government of the Union of Myanmar on Border Trade between the Two Countries. (Ind.-Mmr.). Jan. 21, 1994.

http://commerce.nic.in/india-myanmar-trade-aggment.pdf. 
Ahir, Gangaram (2016, December 6). Starred Question No. 287: Counterfeit Currency. Lok Sabha. http://164.100.24.220/1oksabhaquestions/annex/10/AS287.pdf.

Almost zero insurgent camps on Bangladeshi soil, says BSF chief (2017, December 18). The Times of India. http://timesofindia.indiatimes.com.

Bhasin, A. S. (ed.). (2003). India-Bangladesh Relations, Documents 1971-2002, Vol. IV. New Delhi, India: Geetika Publishers.

Bhasin, A. S. (ed.). (2005). Nepal-India Relations, Documents 1947-June 2005, Vol. IV. New Delhi, India: Geetika Publishers.

Bhasin, A. S. (ed.). (2012). India-Pakistan Relations 1947-2007: A documentary study, Vol. VIII. New Delhi, India: Geetika Publishers.

Bhattacharyya, Rajeev (2010). Small Arms Proliferation in the Northeast: The Chinese Connection. Aakrosh, 13: 49, 46-63.

Central Board of Indirect Taxes and Customs. (n.d.). National Trade Facilitation Action Plan 2017-2020. Retrieved July 21, 2020 from Central Board of Indirect Taxes and Customs. http://www.cbic.gov.in.

Chakraborty, T. (2020, February 28). Land for new border haat between India and Bangladesh. The Telegraph. https://www.telegraphindia.com

Checkpost site at Moreh our land, says Myanmar (2013, December, 25). The Times of India. http://timesofindia.indiatimes.com.

Das, P. (2014). Status of India's border trade: Strategic and economic significance. IDSA Occasional Paper No. 37. IDSA.

Department related Parliamentary Standing Committee on Home Affairs (2018, December, 12). Working Conditions in Border Guarding Forces (Assam Rifles, Sashastra Seems Bal, Indo-Tibetan Border Police and Border Security Force). Rajya Sabha. Retrieved November 4, 2020 from Rajya Sabha website: https://rajyasabha.nic.in/rsnew/Committee_site/Committee_File/ReportFile/15/107/214_2019 _11_11.pdf.

Dogra, S. C. (2012, December 22). From across the border, a trade boom. The Hindu. https://www.thehindu.com.

Four JMB terrorists get 7 years in jail in Burdwan blast case (2020, September 10). The Indian Express. https://indianexpress.com.

Gerstein, Daniel M., Atler, Anthony Aaron, Davenport, C., Grill, Beth, Kadlec, Amanda, \& Young, William (2018). Managing International Borders: Balancing Security with the Licit Flow of People and Goods. Santa Monica: Rand.

Ghosh, P. S. (1989). Cooperation and Conflict in South Asia. New Delhi, India: Manohar.

Government of India. (2001). Reforming national security system: Group of ministers recommendations. Government of India. 
Gupta, Saibal (2017, March 12). Jihadis entering India, warns Bangladesh. The Times of India. https://timesofindia.indiatimes.com.

India, Bangladesh swap border enclaves, settle old dispute. (2015, August 1). The Hindu. https://www.thehindu.com.

Jamwal, N.S. (2002). Terrorist Financing and Support Structure in Jammu and Kashmir,' Strategic Analysis, 26:1, 140-150. doi: 10.1080/09700160208450030.

Kalyanaraman, S (2010). India and the Challenge of Terrorism in the Hinterland. Strategic Analysis, 34: 5, 702-716. doi:10.1080/09700161.2010.501589.

Kanwal, R. (2016, January 8). BSF jawan held for helping arms, drugs smugglers infiltrate into Punjab. India Today. http://indiatoday.intoday.in.

Karlekar, Hiranmay (2014, February 8). The Great Chittagong Arms Haul and India. Pioneer. http://www.dailypioneer.com.

Mehta, P. (2019, March, 6). West Bengal government delaying India-Bangladesh border fence, says Rajnath Singh. Zee News. https://zeenews.india.com.

Ministry of Commerce \& Industry (2017, March 27). Trade Facilitation Agreement of WTO [Press Release]. https://pib.gov.in.

Ministry of External Affairs (2004). Annual Report 2003-04. New Delhi, India: Government of India.

Ministry of Home Affairs (1989). Annual Report 1988-89, New Delhi, India: Government of India.

Ministry of Home Affairs (2004). Annual Report 2003-04. New Delhi, India: Government of India.

Ministry of Home Affairs (2005). Annual Report 2004-05. New Delhi, India: Government of India.

Ministry of Home Affairs. (2008). Annual Report 2007-08. New Delhi, India: Government of India.

Ministry of Home Affairs (2009). Annual Report 2008-09. New Delhi, India: Government of India.

Ministry of Home Affairs (2013). Annual Report 2012-13. New Delhi, India: Government of India.

Ministry of Home Affairs (2014), Annual Report 2013-14. New Delhi, India: Government of India.

Ministry of Home Affairs (2019). Annual Report 2018-19. New Delhi, India: Government of India.

Muslim United Liberation Tigers of Assam (n. d.). Retrieved November 4, 2020, from South Asia Terrorism Portal: http://www.satp.org. 
Nandy, C. (2005). Illegal migration from Bangladesh to India: The emerging conflict". Mellon-MIT Foundation on NGOs and Forced Migration.

Narcotics Control Bureau, (2015). Annual Report 2015. New Delhi: Government of India.

Nepal, India decide to set up boundary working group. (2014, July 15). Business Standard. https://www.business-standard.com.

Niti Aayog (2015). Evaluation Study on Border Areas Development Programme (BADP). PEO Report No. 229. New Delhi, India: Government of India.

Patil, Sameer (2018, April 18). Punjab's unshakable drug smuggling networks. Gateway House. https://www.gatewayhouse.in.

Planning Commission (1992). 8th Five Year Plan, Vol 2. New Delhi, India: Government of India.

Planning Commission (2013). Twelfth Five Year Plan 2012-2017: Vol. I. New Delhi, India: Sage Publications.

Puncchi, M.M. (2010). Internal Security, Criminal Justice and Centre-State Cooperation. Report of the Commission on Centre-State Relations-Volume V. Inter-State Council Secretariat. http://interstatecouncil.nic.in/wp-content/uploads/2015/06/volume5.pdf.

Renaud Egreteau (2008), 'India's Ambitions in Burma: More Frustration Than Success?'. Asian Survey, 48: 6, 936-957.

Sahay, A. (2020, July, 22). BSF jawan dismissed for trans-border drugs and weapons smuggling. The Hindustan Times. https://www.hindustantimes.com.

Sharma, Kartikeya (2013, November 6). Pakistan officially printing fake Indian currency notes. India Today. https://www.indiatoday.in.

Shapoo, Sajid Farid (2016, November 20). How India Can Stop the Next Fake-Money Crisis. The National Interest. https://nationalinterest.org.

Shivananda H. (2011, April 13). Nexus of Drug Trafficking and Militancy Exposed at New Delhi. IDSA Comment. https://idsa.in.

Singh, S. (1999). Growth and Functional Dynamics of the Border Security Force. New Delhi, India: Trikuta Radiant.

Sitharaman, Nirmala (2019, July 15). Starred Question no. 311: Fake Currency. Lok Sabha. http://loksabhaph.nic.in/Questions/QResult15.aspx?qref=3724\&lsno=17.

Smith, Chris (1995). Light Weapons and Ethnic Conflict in South Asia. In Jeferry Boutwell (Ed.), Lethal Commerce. Cambridge, England: American Academy of Arts and Science.

Survey of India (2018). Annual Report 2017-18. New Delhi, India: Department of Science and Technology.

Swami, Praveen (2004). Failed Threats and Flawed Fences: India's Military Responses to Pakistan's Proxy War. India Review, 3:2, 147-170. doi:10.1080/14736480490465045. 
Tripathi, Rahul (2017, May 22). Fake Rs. 2,000 notes seized in Dhaka, NIA sees Pakistan link in supply chain. The Indian Express. https://indianexpress.com.

Two crore illegal Bangladeshis living in India: Government (2016, November 16). The Indian Express. https://indianexpress.com.

Upadhyay, Archana (2009). India's Fragile Borderlands: The Dynamics of Terrorism in the Northeast. London, England: L. B. Tauris \& Co. Ltd.

Voluntary retirement in paramilitary forces rises by $450 \%$, Rijiju tells Rajya Sabha (2018, July 12). The Economic Times. https://economictimes.indiatimes.com.

Widdowson, D., \& Holloway, S. (2011), "Core border management disciplines: Risk based compliance management”. In Gerard McLinden et al. (eds.), Border management modernization (pp. 95-114). World Bank. 